\section{Baserc SciencePark Research, Organization \& Counseling \\ Global Journal of Foreign Language Teaching}

Volume 7, Issue 4, (2017) 137-149

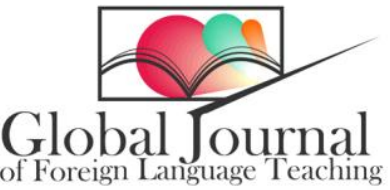

www.gjflt.eu

\title{
Fostering foreign-language teaching at university by developing students' autonomy: The exploratory experiment
}

Karine Chiknaverova*, MGIMO-University, Russian Federation, 10100, Russia.

\section{Suggested Citation:}

Chiknaverova, K. (2017). Fostering foreign-language teaching at university by developing students' autonomy: The exploratory experiment. Global Jou rnal of Foreign Language Teaching. 7(4), 137-149.

Received date; revised date; accepted date.

Selection and peer review under responsibility of Assoc. Prof. Dr. Ali Rahimi, Bangkok University, Thailand.

${ }^{\odot} 2017$ SciencePark Research, Organization \& Counseling. All rights reserved.

\begin{abstract}
This artide addresses the issue of activation of the process of foreign-language acquisition by means of fos tering students' autonomy. The author characterises and analyses the nature and components of foreign-language communicative competence and a utonomy. It proceeds with jus tifying the appropriateness of using particular diagnostic tes ts and specifies the components of autonomy that a re manifested during foreign-language tea ching and lea ming at university. The methods employed include statistical relevance check based on the criteria of Mann-Whitney, Wilcoxon rank correlation, analysis by Spea man and factor analysis. The findings confirm the interconnection between intensity and quality of students' foreignlanguage communicative competence development and their autonomy. The research identifies three levels of foreignlanguage communicative competence and the levels of autonomy corresponding to them. The article condudes with an outline of the stages following the explora tory experimentand further recommenda tions.
\end{abstract}

Keywords: Leamers' autonomy, foreign-language communicative competence, monitoring leamers' autonomy, foreignlanguage a cquisition, English as a second language.

\footnotetext{
* ADDRESS FOR CORRESPONDENCE: Karine Chiknaverova, MGIMO-University, Russian Fe de ration, 10100, Russia.
} E-mail address: chikna verova@mail.nu 


\section{Introduction}

Problems of students' independence, autonomy and self-regulated learning have been the focus of researchers' attention for quite a long time. Much of the research is dedicated to the problems of independent learning activity and work, and the principles and methods of their organisation. However, in practice, teachers often complain about the students' dependence in the course of training, their inability to organise and control themselves, the latter being components of autonomy, which have a significant impact on the quality and speed of teaching foreign languages (Ozcan \& Bicen, 2016; Uzunboylu \& Selcuk, 2016). In this regard, the diagnostics of autonomy in the process of formation and development of foreign competencies makes it possible to determine the level of students' autonomy as well as the degree of interdependence of the processes of foreign competences development and autonomy, it also helps to identify obstades and further on adjust the teaching methodology (Arjmand \& Khorasani, 2016; Birkollu, Yucesoy, Baglama \& Kanbul, 2017; Yavuz, 2017).

In recent decades, studies devoted to the formation and development of foreign-language communicative competence of students at different levels of education, psychological and akmeological laws and mechanisms of foreign-language communicative competence development (Ek, 1986; Gal'skova, 2003; Geikhman, Hymes, 1984; Safonova, 2004; Rivers, 2002; Solovova, 2004), problems of structure, axiological properties of foreign-language competence (Sakharova, 2004), the development of professional foreign-language competences (Iskandarov, 2000; Konnova, 2003), peculiarities of development of this type of competence in the context of contextual and problemproject approaches (Aitov, 2003) have assumed particular salience in the field of foreign-language education.

Analysis of the scientific literature allows us to state that the problem of autonomy is vital in modern pedagogical and psychological sciences as evidenced by the research dealing with issues of independence, self-education, autonomy and similar concepts have been actively investigated (Dam, 1995; Gal'skova, 2003; Holec, 1981; Koryakovtseva, 2002; Little,2000), such as the issue of autonomy in cognition and communication and the matters of autonomy and activity of the individual (Kovalev, 1983). Psychological and psycholinguistic studies focus on the interconnection between the development of cognitive processes and formation of certain personality qualities (Basoz \& Can, 2016) as well as interrelation between various parameters of language acquisition and language development and the development of personality qualities, in particular, those related to volitional and intellectual spheres (Brushlinskij, 1996; Eiger \& Rapoport, 1991; Leont'ev, A. A., 2007; Leont`ev, A. N., 2004; Vygotsky, 2000).

However, we have not revealed a comprehensive study of the problem of interconnection between students' foreign-language competences development and their autonomy as well as studies related to the development of students' autonomy diagnostic tools and aimed at revealing the degree of interconnection and interdependence between the processes of teaching and learning a foreign language and those fostering autonomy.

\section{The scope and Purpose of Research}

The purpose of this study is to identify the parameters of autonomy that are manifested in the course of university students' training in general and those revealed in the course of foreign-language teaching and learning at university. Furthermore, it is aimed to determine a toolkit that can be useful for diagnosing the level of students' autonomy and foreign-language communicative competence in the process of teaching a foreign language and finally identifying and describing the levels of autonomy and foreign-language communicative competence of students. 
In general, pedagogical issues related to activating personality potential have multiple implications. The examination of the issue in the context of foreign-language teaching made the research more specific and the relevant results more conclusive.

The overall experiment took several years and comprised the exploratory stage, as well as introduction, teaching and control. This paper describes the exploratory experience and outlines the possibilities of further research and experiment in the conclusion.

At the exploratory stage we had the following objectives:

- $\quad$ to specify the general parameters of autonomy;

- to identify correlation ties between autonomy parameters;

- to identify the cluster structure of autonomy;

- to specify autonomy's structure as manifested in the process of foreign-language teaching;

- to determine and describe the levels of autonomy based on the preliminary testing of students in the process of teaching and leaming a foreign language;

- to determine and describe levels of foreign-language communicative competence of students as manifested in the process of their autonomy development.

\section{Methods}

To conduct the exploratory experiment, a sample of 677 students of the Russian State University for Humanities (Moscow) was identified. The general characteristics of the sample are provided in Table 1.

Table 1. General characteristics of groups participating in the experience

1. Studen ts of the same year (2nd year of bachel or studies), age and gender;

2. Groups with similar academic achievements, levels of the foreign language (English) and autonomy;

3. Single unified methodology of statistical processing of data; the to tal time of study in each group.

This stage provides for determination of interdependence and interconnection of processes of foreign-language communicative competence formation and boosting their autonomy which in its turn triggers the activity of the learner within and outside the classroom. During this stage we identified the parameters that determine the conditions providing for autonomy, their interdependence and specified the content of this quality as manifested in the course of foreignlanguage communicative competence development. Based on analysis of the scientific literature, three components of students' autonomy were identified (Chiknaverova, 2012). Students were exposed to tests provided in Table 2.

Table 2. Students' autonomy diagnostic tool kit

\begin{tabular}{cl}
\hline \multicolumn{1}{c}{ Autonomy component } & \multicolumn{1}{c}{ Means of diagnostics } \\
\hline Motivation and needs component & $\begin{array}{l}\text { Test aimed at studying motivation in the course } \\
\text { of learning by Rean \&Yakunin; } \\
\text { Test aimed at deter mining students' attitude to } \\
\text { autonomous work by S. Pal'kiy: }\end{array}$ \\
& $\begin{array}{l}\text { Test aimed at deter mination of independence- } \\
\text { Operations and volition component }\end{array}$ \\
& $\begin{array}{l}\text { dependence of personality in the course of } \\
\text { learning by Prygin, 1984. }\end{array}$ \\
& $\begin{array}{l}\text { Questionnaire of learning style by G. } \\
\text { Dombrovetskaya (Leningrad State University) }\end{array}$ \\
& \begin{tabular}{l} 
Diagnostics of self-evaluation by G. Kazantseva \\
\hline
\end{tabular}
\end{tabular}


To confirm the hypothesis, the results were subject to statistical relevance check based on the criteria of Mann-Whitney, Wilcoxon, as well as correlation analysis based on rank correlation by Spearman and factor analysis. The relations between the characters are statistically conditioned, which means that on average a particular unit of one character corresponds to a particular unit or a specter of units. Correlation accounts for concurrent alteration of two attributes, which implies that variability of one attribute corresponds to the variability of another. Although it is difficult to determine whether the reason for a change is inherent in one of the attributes or whether it is beyond them. Correlation can be linear and non-linear, positive and negative. There are cases when there is no correlation but a highly significant curvilinear, polynomial or hyperbolic (Averin, 1995; Demirdag, 2016).

Correlation analysis involves determination of direction (positive/negative), form (linear/nonlinear), establishing correlation between variables, its intensity as well as significance level index check. In this research we used index of rank correlation ( $r$ ) developed by Spearman. It is attributed to nonparametric indexes showing the relation between variables measured within rank scale, it determines the degree of relation between ordinal attributes that constitute the ranks of comparable variables. When determining this index no hypotheses as for character of distribution of attributes in the general totality can be made (Averin, 1995; Kuimova, Uzunboylu \& Golousenko, 2017).

\section{Results}

\subsection{Autonomy as manifested in the process of learning in general}

The data received were processed by the statistics program SPSS, version 1.5 for Windows. The following parameters were measured: learning style (regular/irregular), self-evaluation, motivation (learning (intrinsic), extrinsic, social, professional, defence and avoidance of failure, achievement, creative work), attitude to autonomous work, independence/dependence in leaming. To process the data we applied correlation analysis based on rank correlation of Spearman. The significance level is 0.05 , where $* 5 \%$ is a significance level and ${ }^{* *} 1 \%$ is another significance level. Table 3 contains the most significant correlation links obtained in the course of diagnostics.

Table 3. Significant correlation links

\begin{tabular}{lcc}
\hline \multicolumn{1}{c}{ Variables } & rlndex коэффициент & $\begin{array}{c}\text { Sign Знак } \\
\text { Корреляции }\end{array}$ \\
\hline Independence - self-evaluation & $0.464^{* *}$ & + \\
Independence - learning style & $0.192^{*}$ & + \\
Independence - failure avoidance motives & $0.215^{*}$ & + \\
Independence - communication motives & $0.320^{* *}$ & + \\
Communication motives - failure & $0.429^{* *}$ & + \\
avoidance motives & & + \\
Self-evaluation - attitude to autonomous & $0.310^{* *}$ & + \\
work & & + \\
Self-evaluation - communication motives & $0.547^{* *}$ & + \\
Self-evaluation - failure avoidance & $0401^{* *}$ & + \\
motives & & + \\
Learning style - communication motives & $0.224^{*}$ & + \\
Learning style - failure avoidance motives & $0.312^{* *}$ & + \\
Attitude to autonomous work - creative & $0.281^{* *}$ & \\
work motives & & $0.330^{* *}$ \\
Attitude to autonomous work - learning & & \\
motives & & + \\
\hline
\end{tabular}

$$
*
$$$$
* *
$$ 
In addition to those provided in the table we revealed the direct correlation between the internal and external positive motivation. The higher the learning motivation is the more significant the motives of professional, personal and pragmatic achievements. However, there is negative correlation between communication and learning motives on the one hand and failure avoidance motives on the other. Efficient autonomous work provides for a positive attitude to this type of activity, and contributes to higher self-evaluation, confidence, students' success orientation and reduction of anxiety.

The links that are formed in the course of correlation analysis are referred to as clusters of variables that are relatively closely tied. This cluster is characterised as stable and reliable. Such attributes as learning motivation and attitude to autonomous work (referred to as the cores of the constellation) are of special significance as they have the maximum number of relations. The final diagnostic tool was factor analysis, which provided for conclusive and informative findings. These data en abled us to identify the structure of the autonomy. This analysis provides for standardisation of the variables (z-transformation); after that the correlation variables between the given variables are computated with the help of the standardised value. The correlation matrix serves as the initial element. To build a correlation matrix it is critical to determine the eigenvalue and the eigenvectors corresponding to them, which are identified by means of relative variance of prime factors. Elements of simple vectors factor weights serve as correlation coefficient between variables and factors (Ermolaev, 2002; Agabekova, 2017).

We provide the factor matrix analysis in Table 4. The table contains the factor weights that have the highest absolute value. Separate variables are included into one factor on the basis of the correlation coefficient, this attribution is single valued apart from the 7th variable - attitude to autonomous work, which has similarly strong correlation with two factors (motivational $-0,60$ and axiological -0.546 ).

Table 4. Factor distribution of autonomy parameters

\begin{tabular}{|c|c|c|c|}
\hline No. & Factor & Indicia of factor & Factor value \\
\hline \multirow[t]{3}{*}{1} & Motivational & Learning motivation & 0.863 \\
\hline & & Motivation of achievement & 0.787 \\
\hline & & Attitude to autono mous work & 0.600 \\
\hline \multirow[t]{2}{*}{2} & Axiological & Self-evaluation & 0.598 \\
\hline & & Attitude to autonomous work & 0.546 \\
\hline \multirow[t]{2}{*}{3} & Regulatory & Independence & 0.719 \\
\hline & & Regular style of learning activity & 0.681 \\
\hline
\end{tabular}

Ultimately three factors were revealed. The first having the maximum variance -34 , combines motivation parameters: learning motivation, achievement motivation and attitude to autonomous work by $72 \%$, these two have the maximum value in this factor. The second factor, referred to as axiological, embraces such variables as self-evaluation and attitude to autonomous work. The third factor called regulatory included independence and regular style of learning activity. We can employ various analysis criteria in order to determine the degree of development of factor structures and their stability. One of them is informativity, which indicates the contribution of each factor to the whole factor structure. Moreover, the relations between the factors can be both asymmetric and symmetric, which determines the degree of development of the whole factor structure. Comparing the variances of the factors obtained the asymmetry between factors 34 (72\%), 22 (51\%), 18 (15\%) can be traced. Asymmetry between factors when variance of one of them clearly exceeds the variance of the rest of them signifies the hierarchical nature of the whole factor structure, which in it turn characterises its sustainability. The value of the motivation factor exceeds the remaining ones to a great extent. Thus, intrinsic and extrinsic motivation can be treated as the leading ones in the factor structure of autonomy. Upon comparing the remaining two factors of autonomy by the degree of their 
intensity, we revealed the figures of $22(51 \%)$ and $18(15 \%)$. The proximity of quantitative assessment of axiological and regulatory factors signifies their strong correlation. In terms of their content, it implies that neither of them prevails in the structure of students' autonomy.

Summarising the findings obtained via factor matrix analysis, it is noted that the factor structure of autonomy is a hierarchical and integrated unity, which is characterised by cohesion of characteristics related to personality and behaviour. As such, the motivation mechanism is manifested as the leading one.

\subsection{Autonomy as manifested in the process of learning a foreign language}

The findings were useful in identifying students' autonomy structure in the course of learning in general without specification of its peculiarities manifested in the process of learning a foreign language. During the second series of experiments, we specified the manifestations of autonomy in the course of developing foreign-language communicative competence. They included motivation, evaluation and regulation as well as organisation and action-related components. The means of their diagnostics were specified in accordance with the revealed parameters. Table 5 specifies the parameters and diagnostic instruments. The instruments are recommended to be used to monitor the degree of autonomy at any stage: introductory, teaching or final.

Table 5. Diagnostic toolkit

\begin{tabular}{ll}
\hline \multicolumn{1}{c}{ Component of autonomy } & \multicolumn{1}{c}{ Tool of diagnostics } \\
\hline Needs and motivation & Learning motivation test by A. Rean, V. Yakunin, \\
& complemented by V. Leont'ev and modified by N. Badma eva \\
Operation and action related & 'Goal-means-result' test by A. Karmanov \\
Regulation and evaluation & Volitional self-Control test by A. Zverkov, E. Eidman \\
\hline
\end{tabular}

We identified the levels of autonomy as perceived in the course of foreign-language teaching on the basis of the data obtained by means of comparison of the autonomy components research results and methodical diagnostics results of the degree of foreign-language communicative competence development.

To reveal the extent of autonomy development in the course of foreign-language teaching, we had to determine the degree of each of its components' development by means of identifying:

1. Autonomy's quality assessment criteria.

2. Autonomy's quality assessment indices.

3. Degrees of manifestation of autonomy's quality assessment indices.

The quality of motivation component is determined by the personality significant criterion. Its manifestation is motivation and personal significance of learning for the student at high, medium and low levels. It involves intrinsic, extrinsic, professional, social motivation, communication, failure avoidance, prestige and creative work motivation.

Regulation and evaluation component is determined by the degree of development of reflexive, evaluating and self-regulating skills. Its manifestation is the degree of their development. The level of manifestation is determined by: 1 . volitional self-control (high, medium, low); 2 . self-regulation (high, medium, low); and 3. persistency (high, medium, low).

The operation and action-related component is determined by the learning, operational criteria. Its manifestation is readiness for independent learning. It is manifested at different levels (high, medium, low) of goal-setting, ability to assess the situation and the result. Subject to the manifestations of the components, three levels of autonomy are identified (high, medium, low). 
Table 6. Levels of students' autonomy as manifested in the course of foreign-language teaching and learning

\begin{tabular}{|c|c|c|c|}
\hline $\begin{array}{l}\text { Levels } \\
\text { components }\end{array}$ & Low & Medium & High \\
\hline $\begin{array}{l}\text { Regulation and } \\
\text { evaluation }\end{array}$ & 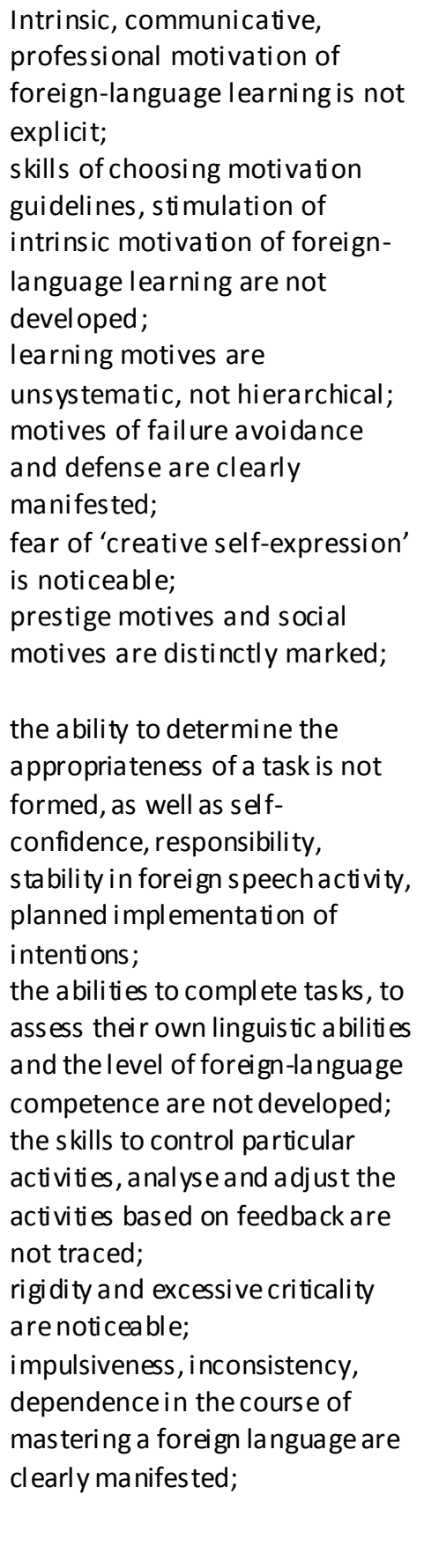 & 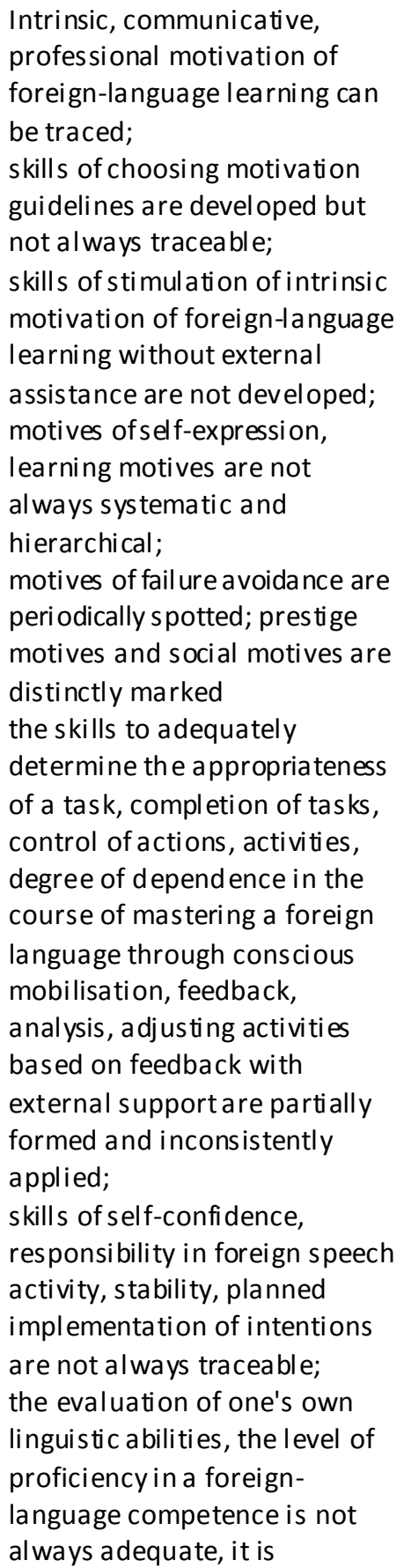 & $\begin{array}{l}\text { Intrinsic, communicative, } \\
\text { professional motivation of } \\
\text { foreign-language learning } \\
\text { is distinctly marked; as well } \\
\text { as skills of choosing } \\
\text { motivation guidelines, } \\
\text { stimulation of intrinsic } \\
\text { motivation of foreign- } \\
\text { language learning; } \\
\text { learning motives are } \\
\text { always systematic and } \\
\text { hierarchical; } \\
\text { failure avoidance motives } \\
\text { are not traced; } \\
\text { creative self-expression is } \\
\text { distinctly marked; prestige } \\
\text { motives and social motives } \\
\text { are traced, but they are not } \\
\text { prevalent } \\
\text { the skills to adequately } \\
\text { assess the appropriateness } \\
\text { of a task, to analyse and } \\
\text { adjust activities based on } \\
\text { feedback, to complete } \\
\text { tasks, as well as self- } \\
\text { confidence, responsibility } \\
\text { in foreign speech activity } \\
\text { are distinctly expressed; } \\
\text { stability, planned } \\
\text { implementation of } \\
\text { intentions are typical; } \\
\text { views on one`s own } \\
\text { linguistic abilities, the level } \\
\text { of knowledge of a foreign } \\
\text { language are realistic; } \\
\text { independence, the ability } \\
\text { to control one's actions, } \\
\text { masting a foreign } \\
\text { lange of }\end{array}$ \\
\hline
\end{tabular}


Operation and the ability to set constructive action related goals and to achieve them in the course of language learning is not formed; the skills of setting 'micro goals' or global goals are prevalent; there is a constantlack of means to achieve the goals; not all actions are appropriate; skills of organisation, planning, modelling, time optimisation when performing tasks are not developed;

the abilities to choose a learning strategy and adequately evaluate the results obtained are not formed the skills of setting real constructive goals, choosing adequate means to achieve them, organising, planning, modelling, optimi sing when performing tasks are partially formed;

the skills to choose a strategy for learning a foreign language without external assistance, to adequately evaluate the results of the productive, receptive speech activity in a foreign language are not formed the skills of realistic goalsetting in the process of learning a foreign language, the ability to choose the means of achieving a goal, as well as organising, planning, modelling, optimising when performing tasks are clearly manifested; as well as the skills to choose an adequate strategy for learning a foreign language, to adequately evaluate the results obtained

Types of work to determine the level of foreign-language communicative competence as boosted by development of students' autonomy included:

- semantic compression of the text (abstracting, annotating, presenting in one sentence, selecting key words, retelling the main content with omissions, retelling by conveying the basic content); processing information (structuring, classification, ordering); forming a semantic range (discursive competence);

- restoration of the text (correction of mistakes in the text, restoration of distorted texts), restoration of a sentence by its denotative structure; morphological reconstruction; addition, actuali sation of life experience, associative semantisation/forecasting; forecasting the structure; deduction/induction; explication of background knowledge (strategic competence);

- the level-by level (words, collocations, sentences, text), content-contextual comprehension; analysis, recognition, differentiation, interpretation of lexical units, grammatical, morphological forms; syntactic constructions, the compatibility of words, synonymous differentiation; lexical grammatical transformations; translation (linguistic competence);

- establishment of correlation and comparison of concepts and categories/realia/personalities/organisations/abbreviations/documents/events); identification of conceptual and terminological lacunas; recognition of elements of the socio-cultural context (necessary for translation, comprehension) (socio-cultural competence);

- identification of genre characteristics, sources of text; selection of informational, analytical, educational texts of different genres, subjects; evaluation of the information received in terms of its relevance, prospects of its use in a professionally-oriented situation; determination of objectivity/bias of the presented position (sociolinguistic competence).

Indicators of autonomy are: skills of goal-setting; reformulation of the problem into a goal; facilitation; optimisation; completion of tasks; selection of task implementation/results verification; anticipating the result/evaluating a process, the result of the proposed task; the planned implementation of intentions; persistence in intentions realisation; criticality; reflection on motivation; responsibility.

Indicators of foreign-language communicative competences development are the ability (1) to use individual resources of vocabulary, grammar and phonetics of the professionally oriented foreign language; (2) to recognise/differentiate/apply the regalia of the language at issue, professionally oriented terms, other language units with socio-cultural connotations in different spheres and situations; (3) to recognise/differentiate/apply ethical-usual norms of speech for communication in 
various spheres and situations; interpret language forms based on a professionally oriented situation; (4) to carry out semantic compression, to process information; (5) restore the language material; to provide language associations, language forecasting.

While observing students in the process of leaming (with the help of protocols) the indicators of autonomy were unchanged to assess all the allocated skills with the focus on linguistic and professional indicators. Below we provide the content of each component of foreign-language communicative competence.

Linguistic:

- recognition, use of lexical units; grammatical, morphological forms;

- recognition, use of syntactic constructions;

- content-contextual comprehension.

- Sociocultural:

- recognition of elements of the socio-cultural context;

- comparative analysis;

- the use and transformation of language forms based on the socio-cultural context.

- Sociolinguistic:

- highlighting genre characteristics;

- situational interpretation;

- use and transformation of language forms based on the situation.

\section{Discursive:}

- abstracting and annotation;

- structuring, classification;

- forming of a semantic range.

- Strategic:

- morphological, syntactic reconstruction;

- structural, semantic, associative forecasting;

- actualisation of life experience.

The total number of errors (formal, functional) were processed and calculated by the formula of the sum of the correct answers/number of responses. The levels of the skills, knowledge, language experience, abilities determined the overall level of the foreign-language communicative competence. These were measured according to the criteria: automation (pauses of hesitation, speed, tension); sustainability (adaptation of skills, abilities, knowledge, language experience to others); inclusion in real foreign-language speaking activity; flexibility (transfer from one situation to another); complication. Oral/written quizzes, the method of experts were used to determine the level of foreign-language competence development. The overall result was reflected in the ratings students are exposed to three times per semester (a 100-point scale). The general level of foreign-language communicative competence development was determined by the quality of skills, knowledge, language experience, and the abilities developed. The level of the competence was also registered with the help of observation protocols (formed on the basis of written/oral quizzes, observation of students' speech activities, conferences, presentations, other public speeches). The protocols were filled in by teachers and experts (the actual score as opposed to the maximum score). The overall result (reflected in the rating) was determined by the formula:

$K=I \times 100 / Q / B \max$

where $K$ accounts for coefficient of competence formation;

$l$ is the sum of points,

$Q$ is the number of students, 
Bmax is the maximum score.

Below we provide description of the levels of foreign-language communicative competence.

Table 5. Levels of students' foreign-language communicative competence

\begin{tabular}{|c|c|c|}
\hline Low & Medium & High \\
\hline $\begin{array}{l}\text { Low level of recognition of } \\
\text { lexical units, grammatical, } \\
\text { morphological forms, syntactic } \\
\text { constructions when being } \\
\text { repeatedly exposed to is } \\
\text { typical; a high percentage of } \\
\text { their incorrect use in the } \\
\text { foreign-language speech; } \\
\text { partial understanding of the } \\
\text { content information, } \\
\text { misunderstanding of the } \\
\text { conceptual and subtext } \\
\text { information; inability to } \\
\text { recognise el ements of a } \\
\text { sociocul tural, sociolinguistic } \\
\text { context; } \\
\text { lack of skills insolving tasks } \\
\text { requiring a nalysis, associative } \\
\text { forecasting, devel oping an } \\
\text { expectation system; } \\
\text { compensatoryskills, skills of } \\
\text { reconstruction are not formed }\end{array}$ & $\begin{array}{l}\text { Contextual recognition of lexical } \\
\text { units, grammatical, } \\
\text { morphological forms, syntactic } \\
\text { constructions when being } \\
\text { repeatedly exposed to is traced; } \\
\text { they are inconsistently us ed in } \\
\text { the forei gn-language speech; } \\
\text { incompl ete understanding of } \\
\text { content, partial understanding of } \\
\text { conceptual, sub-textual } \\
\text { information is typi cal; } \\
\text { partial recognition of el ements of } \\
\text { socio-cul tural, sociolinguistic } \\
\text { context, their inconsistent use is } \\
\text { spotted; logical analysis skills are } \\
\text { underdeveloped; compensatory } \\
\text { skills are prevalent }\end{array}$ & $\begin{array}{l}\text { Contextual and extra-contextual } \\
\text { recognition of lexical units, } \\
\text { grammatical, morphol ogical } \\
\text { forms, syntactic constructions } \\
\text { when being first expos ed to are } \\
\text { typical; they are used correctly } \\
\text { in the foreign-language speech; } \\
\text { full understanding of } \\
\text { meaningful, conceptual, } \\
\text { subtextual information is typical; } \\
\text { most el ements of socio-cul tural, } \\
\text { soci olinguistic context are } \\
\text { recognised, they are us ed } \\
\text { correctly, creative } \\
\text { transformation is applied; } \\
\text { logical and analytical operations } \\
\text { are performed automatically; } \\
\text { skills of reconstruction of } \\
\text { linguistic material, forecasting as } \\
\text { well as skills of devel oping a } \\
\text { system of expectations based on } \\
\text { the experience gained are strong }\end{array}$ \\
\hline
\end{tabular}

Upon completion of the verification and search phase, the results obtained during the testing were analysed and the most effective methodological tools that contributed to the activation of autonomy were included in the course programme at the teaching stage.

In general, three levels of autonomy were singled out in terms of the quality of the indicators: high, medium, low and the corresponding levels of foreign-language communicative competence. The diagnostics of the components of students' autonomy in the process of learning a foreign language and the corresponding diagnostics of their foreign-language communicative competence confirmed the hypothesis of a positive correlation between the processes of foreign-language teaching and developing students' autonomy.

\section{Future Directions and Re commendations}

The exploratory experiment confirmed the possibility and feasibility of intensifying the process of teaching a foreign language by means of fostering students' autonomy fog stage. 
- preparation and organisation of forthcoming experimental training (selection of universities, faculties, selection of experimental and control groups, development of questionnaires).

- development of ways to determine the levels of foreign-language competence development; selection of means of diagnostics of components of autonomy in the process and after the completion of experimental training.

- development of criteria of foreign-language competence development and autonomy;

- supervision of classroom/extracurricular speech activity;

- preparation for experimental teaching by maintaining the records of classes, conducting interviews, psychological diagnostics, making questionnaires in order to determine the initial level of autonomy and foreign-language competence;

- identification of conditions and opportunities for autonomy development in the course of foreign-language teaching and learning; as well as of methods, forms and strategies of experimental teaching.

- conducting theoretical seminars with teachers on the practice of foreign-language teaching, the tasks of the forthcoming experimental training.

- processing the results of questionnaires, protocols and formulating tasks;

- working out the hypothesis of the study, provisions for the creation of a methodological conception of teaching a foreign language on the basis of fostering students' autonomy.

It is also relevant to study the issue of pedagogical effectiveness and the potential of classroom activities. This part of the experimental work can give an answer to question of how effective the experimental forms, methods, strategies and exercises are, whether they are appropriate to be used to foster students' autonomy in the process of developing their foreign-language competences. In the process of goal-setting, the teaching style and methods shall be revisited in terms of their contribution to the development of autonomy in the process of teaching a foreign language.

The final and intermediate goals, as well as the working hypothesis shall be determined, the subject and object of the study shall be specified as well as tasks, organi sational and didactic conditions of experimental training are supposed to be formulated.

The teaching experiment (stage) is recommended to be carried out in natural conditions of teaching in three stages: introductory, procedural and final.

The teaching stage comprises:

- selection of training content;

- provision of experimental training lessons;

- conducting intermediate tests and quizzes to monitor the level of students' foreign-language competences; intermediate diagnostics of the level of students' autonomy;

- improvements of methods and strategies of teaching;

- intermediate interpretation of the results of the study, correlating them with the hypothesis of the study;

- confirmation of the provisions of the working hypothesis of the study;

- formulation of preliminary conclusions;

- The control stage includes:

- diagnostics of autonomy upon completion of experimental training;

- comparative quantitative and qualitative analysis of diagnostic results, results of testing conducted at different stages of experimental training;

- identification of levels of foreign-language competence and autonomy;

- making correlations between the results and the theoretical conclusions of the study;

- correcting and improving theoretical conclusions of the study.

In addition to the toolkit for diagnosing autonomy, survey methods such as questionnaires, dialogical methods (conversations), analysis of the products of students' activity, testing and 
observation are recommended to be employed. A test used to determine the interfering factors in the process of learning in general and mastering a foreign language in particular, as well as an ad hoc questionnaire aimed at establishing the influence of the style of teaching on the development of the components of autonomy of students, their reflection abilities shall be created. Needs and interests of students, the focus of their motivation and other characteristics can be revealed during discussions. A protocol aimed at observing the activities of students shall be kept at each lesson. The observation shall be selective. The protocol shall be conducted by the author, teachers participating in the experimental training during the sessions. Behavioural characteristics of students and other changes shall be registered according to the previously mentioned components of autonomy.

Upon completion of the experience methodological foundations specifying autonomy fostering and providing for activation of the process of foreign-language teaching shall be formulated, the most effective methods, forms, strategies of organising the process of teaching shall be identified and included in the relevant training program.

\section{References}

Agabekova, Z. (2017). Methods of using onomastics in teaching language and culture. Global Journal of Sociology: Current Issues, 7(2), 104-109. doi:https://doi.org/10.18844/gjs.v7i2.2395

Aitov, V. F. (2007). Problemno-proektnyj podkhod k formirovaniyu inoyazychnoj professional'noj kompetentnosti studentov (na primere neyazykovykh fakul'tetov pedagogicheskikh vuzov) [Problem-project approach to the formation of foreign professional competen ce of students (the example of non-language faculties of pedagogical universities)] (Unpublished Doctoral Dissertation). Herzen State Pedagogical University, St. Petersburg, Russia.

Arjmand, N. (2016). Task complexity and its effects on complexity, accuracy and fluency of EFL learners' written production. Global Journal of Foreign Language Teaching, 6(3), 131-142. doi:https://doi.org/10.18844/ gjflt.v6i 3.1367

Averin, V. A. \& Bukharina, T. L. (1995). Psikhologiya meditsinskogo obrazovaniya. Opyt akmeologicheskogo issledovaniya [Psychology of medical education. Experience in acmeological research]. St. Petersburg, Russia: PPMI.

Badmaeva, N. T. (2005) Metodika dlya diagnostiki uchebnoj motivatsii studentov [Student motivation test]. In A. A. Rean \& V. A. Yakunin (Eds.), Vliyanie motivatsionnogo faktora na razvitie umstvennykh sposobnostej (modification of N. T. Badmaeva, pp. 151-154). Ulan-Udeh, Russia.

Basoz, T. \& Can, D. (2016). The effectiveness of computers on vocabulary learning among preschool children: A semiotic approach. Cypriot Journal of Educational Sciences, 11(1), 02-08. doi: https://doi.org/10.18844/ cjes.v11i1.266

Birkollu, S. S., Yucesoy, Y., Baglama, B. \& Kanbul, S. (2017). Investigating the attitudes of pre-service teachers towards technology based on various variables. TEM Journal, 6(3), 578-583.

Brushlinskij, A. V. (1996). Subekt: myshlenie, uchenie, voobrazhenie [The subject: thinking, teaching, imagination]. Voronezh, Russia: NPO «Modehk».

Chiknaverova, K. G. (2012). Teoretiko-metodologicheskie osnovy razvitiya samostoyatel'nosti u studentov $v$ uchebno-professional'noj deyatel'nosti: monogr [Theoretical and methodological bases of development of independence in students in educational and professional activity] (2nd ed.). Izh evsk, Russia: UdGU.

Chiknaverova, K. G. (2016). Kontseptsiya i metodika razvitiya inoyazychnoj kompetentsii studentov vuza na osnove aktivizatsii ikh samostoyatel'nosti [The concept and methodology for the development of foreign competencies of university students on the basis of activation of their independence]. diss. ... dokt. ped. nauk: 13.00.02. Moskva.

Dam, L. (1995). Learner autonomy: From theory to classroom practice. Dublin, Ireland: Authen tik.

Demirdag, E. (2016). An inquiry concerning assistance sentence item determinative in Azerbaijan Turkish and its synonym in Turkish language. In ternational Journal of Innovative Research in Education, 3(1), 19-24. doi: https://doi.org/10.18844/ijire.v3i1.469 
Eiger, G. V. \& Rapoport, I. A. (1991). Yazyk i lichnost' [Language and personality]. Kharkov, Ukraine: Izd-vo KHGU. Ek, J. A. V. (1986). Objectives for fo reign language lea rning. Strasbourg, UK: Council of Europe.

Ermolaev, O. Y. (2002). Matematicheskaya statistika dlya psikhologov : Uchebnik [Mathematical statistics for psychologists: textbook] M. : Mosk. psikhol.-sots.in-t.

Gal'skova, N. D. (2003). Sovremennaya metodika obucheniya inostrannym yazykam [Modern methods of teaching foreign languages]. - 2-e izd. pererab. i dop. / N. D. Gal'skova. - M. : ARKTI-Glossa.

Gejkhman, L. K. (2006). Kommunikativnaya kompetentnost' professionala [Communicative competence of a professional]. Professional'noe obrazovanie, 3, 28-29.

Holec, H. (1981) Autonomy and foreign language learning. Oxford, UK: Pergamon.

Hymes, D. H. (1984) Vers la competence de communication. Paris, UK: Hatier.

Iskandarova, O. Y. (2000). Teoriya i praktika formirovaniya inoyazychnoj professional'noj kommunikativnoj kompetentnosti spetsialista [Theory and practice of the formation of a professional communicative competence of a specialist in another language]. diss.... dokt. ped. nauk: 13.00.01.Orenburg.

Konnova, Z. I. (2003). Razvitie professional'noj inoyazychnoj kompetentsii budushhego spetsialista pri mnogourovnevom obuchenii $v$ sovremennom vuze [The development of professional foreign-language competence of the future specialist in multi-level education in a modern university]. dis. $d$-ra ped. nauk: 13.00.08. Tula.

Koryakovtseva, N. F. (2002). Sovremennaya metodika organizatsii samostoya-tel'noj raboty izuchayushhikh inostrannyj yazyk [The modern method of organizing independent work of foreign language learners]. M. : Arkti.

Kuimova, M. V., Uzunboylu, H. \& Golousenko, M. A. (2017). Foreign language learning in promoting students' spiritual and moral values. Ponte, 73(4), 263-267.

Leont'ev, A. A. (2007). Yazyk, rech', rechevaya deyatel'nost' [Language, Speech, Speech Activity]. M. : URSS.

Leont'ev, A. N. (2004). Deyatel'nost'. Soznanie. Lichnost' [Activity. Consciousness. Personality]. M. : Smysl; Akademiya.

Little, D. (2000) Focus on learning rather than teaching: why and how? Dublin, Ireland: Trinity Coll ege, Centre for Language and Communication Studies.

Ozcan, D. \& Bicen, H. (2016). Giftedness and Technology. Procedia Computer Science, 102, 630-634.

Prygin, G. S. (1984). Proyavlenie fenomenov 'avtonomnosti zavisimosti' v uchebnoj deyatel'nosti [The manifestation of the phenomena of 'autonomy of dependence' in educational activity]. Novye issledovaniya $v$ psikhologii. №2.

Rivers, W. (2002) Autonomy at all costs: an ethnography of metacognitive self-assessment and self-management among experienced language learners. Modern Language Journal, 85(2), 279-290.

Safonova, V. V. (2004). Kommunikativnaya kompetentsiya: sovremennye podkhody k mnogourovnevomu opisaniyu $v$ metodicheskikh tselyakh [Communicative competence: modern approaches to a multilevel description for methodological purposes]. M.: Evroshkola.

Sakharova, N. S. (2004). Razvitie inoyazychnoj kompetentsii studentov universiteta [Development of foreign language competence of university students]. dis.d-ra ped. nauk : 13.00.08. Orenburg, Russia.

Solovova, E. N. (2004). Avtonomiya uchashhikhsya kak osnova razvitiya sovremennogo nepreryvnogo obrazovaniya lichnosti [The autonomy of students as the basis for the development of modern continuing education for the personality]. Inostrannye yazyki v shkole, 2, 11-17.

Uzunboylu, H. \& Selcuk, G. (2016). Pre-service teachers' self-efficacy beliefs in the context of teacher education Program. Anthropologist, 24(3), 778-787.

Vygotsky, L. S. (2000). Psikhologiya [Psychology]. M. : Izd-vo EHKSMO-Press.

Yavuz, F. (2017). Pre-service teachers' perceptions on foreign language teaching issues. New Trends and Issues Proceedings on Humanities and Social Sciences, 4(1), 55-60. doi: https://doi.org/10.18844/prosoc. v4i1.2052 